\title{
Advance directives of will: nurses' perceptions of benefits and
} new demands

\author{
Diretivas antecipadas de vontade: percepções de enfermeiros sobre os benefícios e novas demandas \\ Directivas anticipadas de la voluntad: percepciones de enfermeros sobre los beneficios y \\ las nuevas demandas
}

\author{
Isabela Saioron \\ Flávia Regina Souza Ramos ${ }^{1}$ \\ Dulcinéia Ghizoni Schneider ${ }^{1}$ \\ Rosemary Silva da Silveira ${ }^{2}$ \\ Luciana Ramos Silveira ${ }^{1}$
}

1. Universidade Federal de Santa Catarina.

Florianópolis, SC, Brazil.

2. Universidade Federal do Rio Grande.

Rio Grande, RS, Brazil.
Corresponding author:

Luciana Ramos Silveira.

E-mail: luramos76@gmail.com

Submitted on 05/03/2017.

Accepted on 08/12/2017.

DOI: 10.1590/2177-9465-EAN-2017-0100

\begin{abstract}
Objective: Knowing the perception of nurses about benefits and new demands brought by the Advance Directives (AD) in their daily work. Methods: Qualitative and exploratory research with data collected in 2016 through semi-structured interviews with 19 nurses from a Hospital in southern Brazil. Data analysis was given by the Discursive Textual Analysis. Results: Three categories emerged: The benefits of using ADs in nurses' daily routine; New demands for professionals related to the AD; The $A D$ relevance for patients and their families. Conclusion: It is significant that legal, cultural and structural changes take place in order to take advantage of the ADs' benefits. It is essential to extend the access to ADs' information as part of care quality promotion regarding the terminal patients.
\end{abstract}

Keywords: Advance Directives; Autonomy; Nursing.

\section{Resumo}

Objetivo: Conhecer a percepção de enfermeiros sobre os benefícios e novas demandas trazidas pelas Diretivas Antecipadas de Vontade (DAV) no seu cotidiano laboral. Métodos: Pesquisa qualitativa e exploratória, com dados coletados em 2016, por meio de entrevistas semiestruturadas com 19 enfermeiros de um Hospital do Sul do Brasil. A análise de dados deu-se por Análise Textual Discursiva. Resultados: Emergiram três categorias: Os benefícios do uso das DAV no cotidiano laboral do enfermeiro; Novas demandas para os profissionais relacionadas às DAV; A relevância das DAV para pacientes e seus familiares. Conclusão: Para os benefícios das DAV serem usufruídos, torna-se importante que ocorram mudanças legais, culturais e estruturais. É essencial que se amplie o acesso às informações a respeito das DAV como parte da promoção da qualidade dos cuidados frente à terminalidade.

Palavras-chave: Diretivas Antecipadas; Autonomia; Enfermagem.

\section{Resumen}

Objetivo: Conocer la percepción de enfermeros sobre los beneficios y las nuevas demandas traídas por las Directivas Anticipadas (DA) en su trabajo cotidiano. Métodos: Investigación cualitativa y exploratoria, con datos obtenidos en 2016, por medio de entrevistas semiestructuradas con 19 enfermeros de un Hospital del Sur de Brasil. El análisis de datos se realizó a través del Análisis Textual Discursivo. Resultados: Emergieron tres categorias: Los beneficios del uso de las DA en el trabajo cotidiano; Nuevas demandas para los profesionales relacionadas con las DA; La relevancia de las DA para los pacientes y sus familiares. Conclusión: Para usufructuar los beneficios de las DA es importante que haya cambios legales, culturales y estructurales. Es esencial que se amplíe el acceso a las informaciones sobre las DA como parte de la promoción de la cualidad de los cuidados frente a los casos terminales.

Palabras clave: Directivas Anticipadas; Autonomía; Enfermería. 


\section{INTRODUCTION}

The process of death in occidental society can still be considered a taboo today, awakening divergent perceptions and positions. Not rarely, situations of conflict occur in the hospital environment, where the terminally ill patient lives with his/her relatives and with health professionals, in relationships that may foment anguish and doubts about the behaviors related to that moment, ${ }^{1-3}$ since it involves not only clinical evaluations, but cultural, ethical, legal, and religious aspects. ${ }^{4}$

Among the professionals involved in the death and dying processes, nurses are very close to the patient and their companions, sometimes with affective bonds more favored by the circumstances of the care, and also, in the face of the decisions that involve ethical conflicts, which can cause greater emotional exhaustion. ${ }^{5}$

In this context, the Advance Directives (AD) appear as an instrument capable of facilitating the resolution of possible conflicts arising from the indecisions regarding the conduct to be taken by health professionals. It proposes to minimize the dilemmas faced in matters related to the end of life. It is a documentary record in which the individual manifests the procedures that he or she would like to be submitted under certain circumstances, expressing their will about them. ${ }^{6-8}$ Through this documentation, the individual is able to make explicit his/hers desires if he/she is unable to manifest his/hers will in the future due to illness.

This proposal came about in the United States in the 1960s, when lawyer Luis Kutner proposed the adoption of the AD, at that time called a living will. Even without a clear differentiation between these terminologies, the term AD (Advance Directives) is more commonly used, also because it was adopted in legal documents. Its purpose was to protect the individual's right to die, solving conflicts between doctors, terminal patients and family members about the decision-making of treatments in the face of terminality. $6,7,9,10$

This valorization of freedom of choice in the face of disease and its own terminality has fostered and still fosters contradictory situations in the face of the legislations of occidental countries that traditionally have the primary objective of protecting human life. While it is possible to identify a growing appreciation of individuals' freedom and protagonism over their respective lives and deaths, it occurs in a process of slowness, fomenting differences in society. ${ }^{4}$

In addition to guarantee the patient autonomy, ADs can also reassure family members and health professionals ${ }^{11}$ regarding the therapeutic behavior to be performed, since considering what the patient wants at the end of life is a difficult decision, demands questions and dilemmas within the ethical and legal framework. ${ }^{12}$ Thus, AD is an instrument with potential impact on nurses' performance, since it can resolve conflicts, support decisions that involve quality and continuity of professional care, and at the same time promote the defense of patients' interests.
Brazil does not have regulations for this decision expressed in a document. Until the present moment, the Federal Council of Medicine, through Resolution No. 1,995, of August $9^{\text {th }}, 2012$, was the only one to express its opinion on the use of ADs as a legal document in the national offices. ${ }^{11,8}$ And there is still no law regulating its use.

In view of this scenario and its weaknesses, it was questioned: how do nurses perceive the use of ADs in the current Brazilian context?

Thus, it was aimed to know the nurses' perception about the benefits and new demands brought by the Advance Directives in the Units of Intensive Care and Medical Clinic of a University Hospital in the south of the country.

\section{METHOD}

This is an exploratory and descriptive study, with a qualitative approach, performed at the Intensive Care Unit (ICU) and Medical Clinics I and II of a University Hospital in southern Brazil. The Intensive Care Unit has a physical space that allows 20 beds; 13 beds are active (two are of insulation and two with hemodialysis support). It should be noted that the ICU has the necessary support to provide care to clinical/surgical situations of any specialty. Medical Clinic I has 29 beds, with only 21 active; Clinic II has 25 beds, all of them active. These units were chosen because of the representative number of severe and/or terminally ill patients, where AD could be more common in the work context.

Nurses were chosen as participants in this study because they are one of the professional categories that are very close to the patient and their companions, and can be exposed to greater emotional exhaustion due to the proximity to the suffering of the other ${ }^{5}$ and, consequently, professionals who suffer more directly the influence of ADs. The inclusion criteria were: to be an effective nurse, hired or nursing resident (the resident is part of the integrated multi-professional health residency project). Exclusion criteria were: professionals on vacation or who were on leave.

The definition of the number of participants met the principles of the snowball method, which consists of choosing key informants who subsequently indicate new contacts from their own personal network, and so on and so the sampling frame can grow at each interview, until the saturation of the data is reached. ${ }^{13}$ The aim of this method was to enable the researcher interviewer to approach in a more subtle way, since the indication by a work colleague could favor that any possible barriers or fears in dealing with the subject would be minimized.

The data were collected from January to March of the year 2016. This stage of the research was done through semi-structured interviews, whose script was planned by the researchers, based on comprehension and application gaps detected in the literature and including a model and explanation 
of this documentation, in case the participants do not know the concept. The questions asked during the interviews dealt with questions about the participants' knowledge about $A D$, how the instrument could influence the systematization of care, what would be the advantages and disadvantages of $A D$ in their daily lives, what difficulties could there be for the document to be approved by the Nursing team, what is their position on the approach of the topic during the training and what is the relevance of $A D$ to patients and their families. The interviews were conducted by the principal researcher who has experience with this methodological strategy. In spite of the limitations resulting from these knowledge gaps, the aim was to elucidate the subject, so that the interview would only continue when the participant was clear. The interviews were performed at the participants' work place, being audio-recorded and transcribed in full. Data collection began after the approval of the Research Ethics Committee involving Human Beings of the Federal University of Santa Catarina (Opinion 1,353,986). The development of the study respected the ethical aspects according to Resolution $466 / 2012$ of the National Health Council.

In the data organization stage, the Atlas-ti software was chosen. The methodological analysis used was guided by Discursive Textual Analysis (DTA), composed of four focuses: 1) disassembly of the texts: the participants' answers were examined;2) establishment of relationships: the responses were grouped, elaborating the categories; 3 ) capture of the emerging new: elaboration of a metatext interpreting the meanings and relating them to the original corpus; 4) self-organized process: movement of a new text through theoretical interlocutions and new understandings about the phenomenon studied. ${ }^{14}$

\section{RESULTS}

The participants of the study are mostly female, had previous experience to their recent professional activity and more than one postgraduate degree, emphasizing the master's and specialization courses. Of the 19 nurses, all had some religious belief. Another striking feature is attributed to the lack of knowledge about $A D$, only three of them were able to define them.

The establishment of relationships based on the methodological proposal made it possible to construct three categories: Benefits related to $A D$ in the hospital context; New demands related to $A D$; The relevance of $A D$ to patients and their families.

Table 1 presents the synthesis of category 1 , the benefits related to $A D$ in the hospital setting.

In the nurses' perception, a greater concern arises with the demands that emerge from the AD. The results are presented in Table 2.

Another category that stood out for nurses was the importance of the topic of $A D$ for patients and their families (Table 3).

\section{DISCUSSION}

Acting with the people involved in the termination process and also with their own emotions involves difficult questions that extrapolate technical knowledge and refer directly to human behavior and values. ${ }^{15,16}$ From this perspective, it was observed that possible weariness generated when facing these situations can be mitigated through the use of $A D$, since it is the expression of the patient's wishes and as such should be considered as a benefit in the process of providing to the patient health care. ${ }^{11}$ This type of benefit was evidenced in categories 1 and 3 , that is, for professionals, patients and their families.

However, the situation is not simple to deal with. With the purpose of the AD, new demands arise (category 2), according to the participants. Under this aspect, legal distress was highlighted, which raises fear and uncertainties, that may prevent the use of the instrument, ${ }^{17}$ since ADs are not legally protected in Brazil, although they are regulated by the Federal Council of Medicine ("CFM") since 2012.

In addition, it was noted in this study that the absence of a clear position regarding the use of the instrument and/ or a guidance from the Federal Nursing Council ("COFEN") regarding ADs makes the nurses reflect on the fact that they are not "assisted" in specific situations like this. Even when informed about the Resolution issued by CFM, the participants took it as a possible support only for medical professionals. For the nursing to feel truly supported, it lacks the manifestation of COFEN through the issuance of its own resolution, aimed at professionals who practice nursing.

It was also observed that, directly and indirectly, the issue of $A D$ exposes the members of the health team and even the relatives and patients to situations that generate conflicts. It is complex to handle conflicts because they depend on the values, beliefs, knowledge and experiences of people who are diverse. In addressing the new demands (category 2 ), which emerge with the use of $A D$, professionals express insecurities that, in a way, are related to the termination process itself. Like ADs, terminality dictates that the health team develop skills and competences for deliberating on conflicts in all its complexity, in an adaptive and sensible way. ${ }^{15}$ In this sense, it is important to point out that in order to deal with the imprecision of the crossing of life, it is essential to be aware of the challenges that sometimes become more mild through a respectful and professional relationship. ${ }^{1}$

From the point of view of the new demands, nurses are apprehensive about the guidelines that contemplate the $A D$ and its relation with the rapid changes of the technological and therapeutic apparatuses. It is pertinent to point out that authors already point to limitations of $A D$. According to them, recognizing their vulnerabilities and understanding them is a great step in contributing to the process of death and dying in a more constructive way. ${ }^{18,6}$ 
Table 1. Category 1 - The benefits of using ADs in nurses' daily routine. Florianópolis/SC, 2016.

\begin{tabular}{|c|c|}
\hline Citations & Capture of new emerging \\
\hline $\begin{array}{l}\text { [...] I think it's a path, it gives you a direction [...] I think it's } \\
\text { a guideline, I agree. Especially if you have the matter of the } \\
\text { tutor, I think it's possible. (P07). } \\
\text { Sometimes the patient has been here for a long time with } \\
\text { us, he/she is lucid, awake and sometimes he/she says he/she } \\
\text { does not want them to do it, he/she does not want to be } \\
\text { intubated, for example, so he becomes unconscious and the } \\
\text { option is to be intubated, then at that moment the document } \\
\text { would give you a backing because he/she left it in writing } \\
\text { that he/she really does not want to, it wasn't just said. } \\
\text { Because sometimes we say and people think it's negligence, } \\
\text { [...] then that document would back up. (P11). } \\
\text { [...] It is very complex to deal with the other's life without } \\
\text { knowing what he/she would like it to be done... sometimes } \\
\text { we leave here heavily in the consciousness of not knowing if } \\
\text { we are really doing the best for the patient, and if he could } \\
\text { give that signal, of what he/she wants for it, I think it would } \\
\text { be very good for our work, very good for the patient [...]. } \\
\text { (P17). }\end{array}$ & $\begin{array}{l}\text { The nurses realized that the use of ADs could benefit the } \\
\text { work, not only of the nursing category, but of the whole } \\
\text { multi-professional team, since being aware of the patient's } \\
\text { real decisions and wishes provides comfort and tranquility } \\
\text { for professionals, in face of decision-making processes } \\
\text { involving unconscious patients. }\end{array}$ \\
\hline
\end{tabular}

The relevance of ADs to patients and their families (category 3 ) is pointed out by nurses, especially the emphasis given to autonomy, as an undeniable principle of unavoidable magnification. For this, it is necessary that clear laws and regulations be drafted so that the self-management of the body and life as a whole, including the death process, is understood, accepted and respected..$^{4,6} \mathrm{It}$ is believed that such conduct may facilitate the acceptance of terminality as a phase of human existence.

In general, ADs may either indicate a waiver of lifeprolonging treatments or a decision that all available measures are applied to maintain life. Thus, patients who have an AD manifest how they would like to be treated in situations of risk of death or in conditions where their ability to decide on their health is compromised. They express their preferences based on their values that will direct the actions of family members and health professionals. ${ }^{19}$ The instrument represents the possibility of recovering patients' autonomy at a time when the patient is unable to take decisions. ${ }^{20}$

However, low education, coupled with insufficient knowledge about hospital procedures and routines, may be a limitation in the exercise of patient autonomy. It is recognized that certain values vary from person to person, and each patient should refuse or receive treatment; ${ }^{21}$ however, autonomy, in order to be exercised in the best possible way, must be based on information. Therefore, the author of the AD needs to have access to information such as the predictable course of certain diseases, survival possibilities, sequelae, among others, so that situations can be properly evaluated before the document is elaborated. ${ }^{11}$
Due to the permanent hope of recovery of the patient and the search for technological advances by family members (category 2 ), it is difficult to define the limits in the care activity. ${ }^{17}$ Respecting a request to limit investments in a patient with viable therapeutic possibilities, thanks to the current technological support, can be a conflict for nurses because of the sense of responsibility and the possibility of personal involvement between caregiver and patient. The need to better reconcile treatments with patients' individual desires is recognized, prioritizing not only their needs in life, but also at the moment of death. ${ }^{17,22,23}$

Nurses were confused and worried about the ambiguous nature of $A D$ that, according to them, bring both benefits and challenges to the patient, family members and health professionals. Because of this paradoxical feature, most of the interviewees could not feel safe to establish an opinion about the application of $A D$ in the reality found in Brazil.

This is a limitation of the study, since many of the findings were generated by a momentary reflection in the interview process, and there is perhaps not enough time for a more in-depth reflection on the subject. However, even with this limitation, nurses were aware of the difficulties and insecurities related to the care of terminally ill patients, so that, even with a lack of prior knowledge about $A D$, it was possible for them to elaborate on the potential benefits and demands of this instrument and managed to consistently relate the use of $A D$ to this daily work.

Despite this situation, nurses have been able to consider that this is a document with significant and beneficial potential, as long as there are legal and cultural changes, both in health 
Table 2. Category 2 - New demands for professionals related to AD. Florianópolis/SC, 2016.

\begin{tabular}{|c|c|}
\hline Citations & Capture of new emerging \\
\hline $\begin{array}{l}\text { [...] He asks me not to intervene, but I want to intervene, [...] } \\
\text { what will defend me? And if I follow, what can interfere with } \\
\text { my profession? Can I face any legal proceedings? (P02). } \\
\text { [...] It is difficult, the professional is here working to maintain } \\
\text { life. They have their own values, religious beliefs, ethics [...] } \\
\text { in a situation like this there may be professionals who are } \\
\text { okay with it, but for another it's not, then this will already } \\
\text { generate a conflict in the team. (P07). } \\
\text { [...] create ethical, or religious, or values conflict, and this } \\
\text { is a very difficult thing to deal with in reality [...] I have } \\
\text { had patients, for example, having lung cancer [...] and the } \\
\text { patient, still lucid, to tell me that he did not want the venous } \\
\text { access, denying the medication and saying that he wanted } \\
\text { to die like that. [...] he/she did not want to stop suffering, } \\
\text { today I think that maybe he believed that he deserved it and } \\
\text { that he might not deserve a quiet death. So it was a very big } \\
\text { conflict because the family split up, part of the family agreed } \\
\text { to his request, another part did not [...]. (P18). }\end{array}$ & $\begin{array}{l}\text { The new demands raise uncertainties in the professionals } \\
\text { and the fear of being submitted to a possible judicial } \\
\text { process. The absence of a clear position regarding the use of } \\
\text { the instrument, or even a Federal Nursing Council ("COFEN") } \\
\text { orientation towards ADs also seems to cause discomfort. In } \\
\text { addition, issues related to emotions, cultural, personal and } \\
\text { religious values generate doubts, anguish, and conflicts in } \\
\text { the relationships between team members and even with } \\
\text { patients and families experiencing terminality. }\end{array}$ \\
\hline Citations & Capture of new emerging \\
\hline $\begin{array}{l}\text { I see this with some concern, documents made in advance, } \\
\text { in many moments of life we value one thing, after some time } \\
\text { we value another, then the other is no longer so important ... } \\
\text { I think we change a lot in life... serious situations make you } \\
\text { wake up to something else. (P10). } \\
\text { Life is so full of surprises, we see people who were } \\
\text { completely sunk and resurfaced, today they are well, they } \\
\text { are at home. It's so unpredictable to know what is going to } \\
\text { happen, whether the person will be fine or homeless. It is } \\
\text { very difficult [...]. (P15). }\end{array}$ & $\begin{array}{l}\text { There was concern about possible disorders arising from } \\
\text { the development of AD. This view can be attributed to the } \\
\text { directives that guide the document and to the rapid process } \\
\text { of transformation of the technological and therapeutic } \\
\text { apparatuses that allow greater success in situations } \\
\text { previously foreseen as without therapeutic possibility. }\end{array}$ \\
\hline
\end{tabular}

institutions, professional bodies and in the community. However, it is essential to broaden access to information on ADs in order to provide support, security and trust, in order to subsidize humanized care. ${ }^{24}$

\section{FINAL CONSIDERATIONS}

Although it is admitted as a limitation of this study, the fact it was perfomed with nurses from a single hospital institution, among which few previously knew the $A D(s)$, it was important to know the nurses' perception about them and their use in the hospital context, since it allowed for approximations/ associations between this new theme and the work reality of these professionals, stimulating important reflections about terminality and autonomy.

Overall, the study demonstrates that ADs can bring greater safety to the health team by performing the complex actions that may be applicable to terminality and, therefore, it was possible to conclude from this study that ADs are an important tool to assist nursing actions. It was also possible to conclude that, in addition to helping nurses, ADs can help patients to exercise the right to autonomy and their families in relation to the issues related to terminality, allowing the better acceptance of death as part of human existence.

However, there were difficulties with the appearance of new demands that may hinder the use of $A D$, among them: legal uncertainties; conflicts in the relationships between professionals, family and patients, generated by cultural differences and beliefs; family insecurity with respect to the autonomy given to the patient; and apprehension about the directives that contemplate the $A D$ and its relation with the rapid transformations of the technological and therapeutic apparatuses.

Thus, the AD were recognized in this study as a partially facilitating instrument of ethical issues involving terminality, since, even without a proper law regulating them, they constitute a functional document capable of acting as a guide for nurses, for other health professionals, as well as for the relatives of the patients. 
Table 3. Category 3 - The relevance of AD to patients and their families. Florianópolis/SC, 2016.

\begin{tabular}{|c|c|}
\hline Citations & Capture of new emerging \\
\hline $\begin{array}{l}\text { There was a situation where a patient had a cancer and he } \\
\text { had a lot of body pain, and we offered to come in with the } \\
\text { morphine pump [...] he surprisingly said no, that he would } \\
\text { rather be in pain but conscious to keep talking to his family, } \\
\text { having his last moments with the family, even with pain [...]. } \\
\text { (P17). } \\
{[\ldots] \text { If the document proves that that is really the will of the }} \\
\text { patient, that it was not a moment of delirium or suffering } \\
\text { that can change the opinion of the person. }(P 18) \text {. }\end{array}$ & $\begin{array}{l}\text { The participants expressed the importance of the autonomy } \\
\text { of the being, in which each individual decides on his own } \\
\text { body. In this sense, ADs would be a tool that will document } \\
\text { the patient's wishes and can facilitate the respect for their } \\
\text { autonomy. }\end{array}$ \\
\hline Citations & Capture of new emerging \\
\hline $\begin{array}{l}\text { [...] In some cases the family does not accept certain } \\
\text { behaviors, this document showing the desire of his relative. I } \\
\text { think it facilitates a lot; For the family, I think it would have a } \\
\text { great advantage, because of the acceptance. (P05). } \\
\text { [...] For the family to decide for the unconscious patient, } \\
\text { which is better for him/her, it is a very big weight, and a } \\
\text { lot of people did not have this conversation before [...] This } \\
\text { week a patient who could be "palliated" was taken to the } \\
\text { ICU Because the daughter could not make the decision, the } \\
\text { brothers were absent, they did not want to get involved and } \\
\text { she alone could not decide and the mother never showed her } \\
\text { will, so it's complicated. (P18). }\end{array}$ & $\begin{array}{l}\text { ADs could bring greater comfort and security for family } \\
\text { members to make decisions; since knowing the real will } \\
\text { of the patient could alleviate possible anxieties generated } \\
\text { by the doubt about the best direction of the situation, } \\
\text { mitigating intra-familial conflicts. In addition, knowing the } \\
\text { patient's real will can aid in the process of acceptance of } \\
\text { terminality by the family. }\end{array}$ \\
\hline Citations & Capture of new emerging \\
\hline $\begin{array}{l}\text { So the advantage of family members is to know what the } \\
\text { patient manifested, but at the right time to apply maybe } \\
\text { the family members may conflict. So we do not even know } \\
\text { the moment they would like to position themselves. It would } \\
\text { create insecurity. (P06). } \\
\text { [...] For example, the relative does not want this and the } \\
\text { patient wants, and then we take a position that would be } \\
\text { related to the patient and the relative can question; what } \\
\text { would weigh would be that part of the family, that we would } \\
\text { be neglecting care. (P11). }\end{array}$ & $\begin{array}{l}\text { Even in the face of the patient's wishes expressed in the } \\
\text { form of } A D \text {, some relatives may disagree with the manifesto, } \\
\text { generating intra-family conflicts and questioning the health } \\
\text { team, especially in cases where there would be a favorable } \\
\text { prognosis in the case of being performed procedures } \\
\text { rejected by the patient. There may be difficulties accepting } \\
\text { the terminality of a loved one. }\end{array}$ \\
\hline
\end{tabular}

Considering the results of the study, it was possible to perceive that, for the benefits of ADs to be taken advantage of, it is important that legal, cultural and structural changes take place to mitigate the impact of the emerging demands on their use, both in health institutions, professional bodies and the community so that ADs can really assist in the nursing performance and, consequently, benefit society as a whole. In any case, it is essential to expand access to information about ADs so that this process of awareness and change can occur, thus enabling a better management of terminality in the future.

\section{REFERENCES}

1. Amorim KPC. O cuidado de si para o cuidado do outro. Rev Bioethikos [Internet]. 2013 Oct/Dec; [cited 2017 Mar 28]; 7(4):437-41. Available from: http://www.saocamilo-sp.br/pdf/bioethikos/155557/a09.pdf. ISSN 2175-3393.

2. Junges JR, Cremonese C, Oliveira EA, Souza LL, Backes V. Reflexões legais e éticas sobre o final da vida: uma discussão sobre a ortotanásia. Rev Bio [Internet]. 2010; [cited 2016 Apr 2]; 18(2):275-88. Available from: http://revistabioetica.cfm.org.br/index.php/revista_bioetica/ article/viewFile/564/537 
3. Santos FPPG, Comassetto I, Porciúncula AIC, Santos RM, Ferreira FAS, Magalhães APN. Ortotanásia e distanásia: percepção dos profissionais de saúde de uma unidade de terapia intensiva. Ciênc Cuid Saude [Internet]. 2016; [cited 2017 Mar 28]; 15(2):288-96. Available from: http://www.periodicos.uem.br/ojs/index.php/CiencCuidSaude/article/ view/26017/17481. http://dx.doi.org/10.4025/cienccuidsaude.v15i2

4. Santos KO. Percepções de enfermeiros intensivistas frente a distanásia: revisão integrativa. Rev Saúde Com [Internet]. 2016 Jan/Mar; [cited 2017 Mar 28]; 12(1):505-13. Available from: http://www.uesb.br/revista/rsc/ ojs/index.php/rsc/article/viewFile/340/362

5. Hermes HR, Lamarca ICA. Cuidados paliativos: uma abordagem a partir das categorias profissionais de saúde. Ciênc Saúde Coletiva [Internet]. 2013 Sep; [cited 2015 Mar 3]; 18(9):2577-88. Available from: http://www. scielo.br/pdf/csc/v18n9/v18n9a12.pdf

6. Cogo SB, Lunardi VL. Diretivas antecipadas de vontade aos doentes terminais: revisão integrativa. Rev Bras Enferm [Internet]. 2015 May/Jun [cited 2016 May 20]; 68(3):524-34. Available from: http://www.scielo. br/pdf/reben/v68n3/0034-7167-reben-68-03-0524.pdf. http://dx.doi. org/10.1590/0034-7167.2015680321i

7. Bomtempo TV. Diretivas antecipadas: instrumento que assegura a vontade de morrer dignamente. Rev Bio Der [Internet]. 2012 Sep; [cited 2017 Aug 31];26:22-30. Available from: http://scielo.isciii.es/pdf/bioetica/ n26/original3.pdf

8. Conselho Federal de Medicina (CFM) (BR). Resolução № 1.995 do Conselho Federal de Medicina. Dispõe sobre as diretivas antecipadas de vontade dos pacientes. Brasília (DF): Conselho Federal de Medicina; 2012 [cited 2015 Mar 30]. Available from: http://www.portalmedico.org. br/resolucoes/CFM/2012/1995_2012.pdf

9. Dadalto L. Reflexos jurídicos da Resolução CFM 1.995/12. Rev Bio [Internet]. 2013; [cited 2015 Mar 15]; 21(1):106-12. Available from: http:// www.scielo.br/pdf/bioet/v21n1/a12v21n1

10. Dadalto L, Tupinambás U, Greco DB. Diretivas antecipadas de vontade: um modelo brasileiro. Rev Bio [Internet]. 2013; [cited 2015 Apr 4];21(3):463-76. Available from: http://www.scielo.br/pdf/bioet/v21n3/a11v21n3.pdf

11. Bermejo JC, Belda RM. Testamento Vital: diálogo sobre a vida, a morte e a liberdade. São Paulo: Loyola; 2015. 104 p.

12. Moreira MADM, Costa SFG, Cunha MLDM, Zaccara AAL, NegroDellacqua M, Dutra F. Testamento vital na prática médica: compreensão dos profissionais. Rev Bio [Internet]. 2017; [cited 2017 May 2]; 25(1):16878. Available from: http://www.scielo.br/pdf/bioet/v25n1/1983-8042bioet-25-01-0168.pdf

13. Vinuto J. A amostragem em bola de neve na pesquisa qualitativa: um debate em aberto. Temáticas [Internet]. 2014; [cited 2017 Mar 29]; 22(44):203-20. Available from: http://www.ifch.unicamp.br/ojs/index. php/tematicas/article/download/2144/1637

14. Moraes R, Galiazzi M. Análise textual discursiva. 2ª ed. ljuí: Unijuí; 2011. $224 \mathrm{p}$.
15. Araújo MMT, Silva MJP, Simone GG, Torales GMG. Inteligência emocional no trabalho em equipe em cuidados paliativos. Rev Bioethikos [Internet]. 2012; [cited 2017 Mar 28]; 6(1):58-65. Available from: http://www.saocamilo-sp.br/pdf/bioethikos/91/a06.pdf

16. Meneguin S, Ribeiro R. Dificuldades de cuidadores de pacientes em cuidados paliativos na estratégia da saúde da família. Texto Contexto Enferm [Internet]. 2016; [cited 2017 Aug 31]; 25(1):e3360014. Available from: http://www.scielo.br/scielo.php?script=sci_arttext\&pid=S010407072016000100312\&lng=en\&nrm=iso

17. Cogo SB, Lunardi VL, Quintana AM, Girardon-Perlini NMO, Silveira RS. Desafios da implementação das diretivas antecipadas de vontade à prática hospitalar. Rev Bras Enferm [Internet]. 2016 Nov/Dec; [cited 2017 Mar 28]; 69(6):1031-8. Available from: http://www.scielo.br/ pdf/reben/v69n6/0034-7167-reben-69-06-1031.pdf. http://dx.doi. org/10.1590/0034-7167-2016-0085

18. Nunes MI, Anjos MF. Diretivas antecipadas de vontade: benefícios, obstáculos e limites. Rev Bio. [Internet]. 2014; [cited 2017 Maio 2] 22(2):241-51. Available from: http://www.scielo.br/pdf/bioet/v22n2/06. pdf. http://dx.doi.org/10.1590/1983-80422014222005

19. Betancur MAL. Nursing care of patients during the dying process: a painful professional and human function. Invest Educ Enferm [Internet] 2015; [cited 2016 Jun 14]; 33(2):297-304. Available from: http://www. scielo.org.co/pdf/iee/v33n2/v33n2a12.pdf. http://dx.doi.org/10.17533/ udea.iee.v33n2a12

20. Tschirhart EC, DU Q, Kelley AS. Factors influencing the use of intensive procedures at the end of life. J Am Geriatr Soc [Internet]. 2014 Nov [cited 2016 Jun 14]; 62(11):2088-94. Available from: https://www.ncbi. nlm.nih.gov/pmc/articles/PMC4241150/pdf/nihms620330.pdf

21. Tealdi JC. Diccionario latinoamericano de bioética. Bogotá: Unesco Red Latinoamericana y del Caribe de Bioética, Universidad Naciona de Colombia; 2008. $660 \mathrm{p}$.

22. Zwijsen SA, Nieuwenhuien NM, Maarsingh OR, Depla MFIA, Hertogh CMPM. Disentangling the concept of "the complex older patient" in general practice: a qualitative study. BMC Fam Practice [Internet]. 2016 Jun; [cited 2016 Jun 15]; 17:64. Available from: http://www.ncbi.nlm.nih. gov/pmc/articles/PMC4891906/pdf/12875_2016_Article_455.pdf.DOI: 10.1186/s12875-016-0455-6

23. Kovács MJ. A caminho da morte com dignidade no século XXI. Rev Bio [Internet]. 2014; [cited 2017 May 2]; 22(1):94-104. Available from: http:// revistabioetica.cfm.org.br/index.php/revista_bioetica/article/view/886

24. Brito FM, Costa ICP, Costa SFG, Andrade CG, Santos KFO, Francisco DP. Comunicação na iminência da morte: percepções e estratégia adotada para humanizar o cuidar em enfermagem. Esc Anna Nery [Internet]. 2014; [cited 2017 May 2]; 18(2):317-22. Available from: http:// www.revistaenfermagem.eean.edu.br/detalhe_artigo.asp?id=1085. DOI: 10.5935/1414-8145.20140046. 